\title{
Çağdaş Müze Sergi Mekânlarında Hikâye Anlatımının Sergileme Vitrinleri ve Vitrin Aydınlatma Tasarımına Etkisi
}

\author{
Züleyha AYKUT ${ }^{1}$
}

Öz

Müzelerin giderek sergi mekânlarında sürükleyici bir müze deneyimi yaratmak için hikâye anlatımı ile kurgulanan tasarımlara yer verdikleri görülmektedir. Hikâyenin anlatılabilmesi için sergi konusunun bir teması olmalıdır. Sergileme mekân tasarımı gerçekleştirilirken, serginin temasını destekleyen tasarım öğeleri arasında aydınlatmanın ve vitrin tasarımlarının rolü çok önemlidir. Bu nedenle çalışma kapsamında müze aydınlatmaları içerisinde önemli bir yeri olan vitrinler ve aydınlatma tasarımına yer verilecektir. Vitrinlerin aydınlatmaları ile birlikte ziyaretçilerinin ilgisini çekecek form, renk ve işlevsellikte diğer tasarım öğeleri ile ilişkilendirilerek tasarlanması gerekmektedir. Vitrin ve aydınlatmalarının, müze sergilemelerinin hikâye anlatımının ziyaretçilere ulaştırılmasında ve temanın belirleyiciliği konusunda önemli rol üstlendiği çalışma kapsamında irdelenmeye çalışılmıştır. Çalışmada vitrinlerin ziyaretçinin görsel konfor gereksinimlerini sağlayacak ilkeler doğrultusunda ve hikâye anlatımını destekleyen estetik değerde tasarlanması gerektiği amaçlanmıştır. Bu bağlamda çalışma, müze vitrin aydınlatmalarının müze deneyiminin çekiciliğini artırıcı yönlerini ve tasarımın hikâye anlatımına, görsel konfor ve müze deneyimine etkisini ortaya koymaktadır. Araştırmada, bu amaçla çağdaş müze sergi mekânlarında yapılan vitrin ve aydınlatma tasarımlarının hem görsel konforu sağlayacak hem de sergi temasını vurgulayacak nitelikte gerçekleştirilmesi gerektiği değerlendirilmiştir. Araştırma, nitel araştırma yöntemlerinden betimsel tarama modeli kullanılarak gerçekleştirilmiştir.

Anahtar Kelimeler: Çağdaş müze sergi mekânı, Müze vitrin tasarımı, Vitrin aydınlatma tasarımı, Hikâye anlatımı, Görsel konfor

\section{The Effect of Storytelling in Contemporary Museum Exhibition Places on Exhibition Showcases and Showcase Lighting Design}

\begin{abstract}
Abstarct
\footnotetext{
${ }^{1}$ Mimar Sinan Üniversitesi, Fen Bilimleri Enstitüsü İç Mimarlık Doktora Programı

It is seen that the museums present designs built with story telling to enable a fascinating museum experience in their exhibition spaces. In order to tell the story, the subject of the exhibition must have a theme. In designing the exhibition space, the role of lighting and showcase designs are vital among the design items supporting the theme of the exhibition. Therefore, showcases and lighting design having an important place in museum lighting will be included in the scope of this study. The showcases must be designed in conjunction with lighting along with other design items such as forms, colors, and functionality. The showcases and lighting playing important roles for delivering the story telling to the visitors and the decisiveness of the theme have been examined within the scope of this study. In the present study, it is aimed to point that 
the showcases should be designed in line with the principles enabling the visual comfort of the visitors and in an aesthetic value supporting the story telling. In this context, the study at hand asserts the aspects of showcase lighting improving the attractiveness of the museum experience and effects of the design on storytelling, visual comfort and museum experience. In the research conducted, it was evaluated that the showcase and lighting designs made in contemporary museums should be performed in a manner to enable both visual comfort and emphasizing the theme of the exhibition. The research was conducted by utilizing a descriptive survey model, one of the qualitative research methods.

Keywords: Modern Museum Exhibition Space, Museum showcase design, showcase lighting design, Storytelling, Visual Comfort

\section{Giriş}

Müze sergi mekânlarında aydınlatma, görsel-işitsel ve anlatı aracılığıyla sunulan hikâye anlatımını destekleyen önemli tasarım öğelerinden biridir. Ziyaretçinin görsel konforunun sağlanabilmesinde ve deneyim edinmesinde aydınlatma sistemlerinin önemli bir yeri vardır. 20. yüzyılda değişen sergi tasarımları yaklaşımı ile birlikte müzelerin, ziyaretçi merkezli, mekânlarını ilgi çekici, aktif katılımı teşvik eden ve merak uyandıran kurgusal mekânlara dönüştürme çabasına girdikleri izlenmektedir. Bu çekiciliğin sağlanabilmesi için nesnelerin yeni bir anlayışla hikâyeleri ile birlikte ve bu hikâyelerin de vitrin aydınlatma tasarımlarını destekleyecek biçimde sunulması gerekmektedir.

Çağdaş müze ve sergi mekânlarının vitrin aydınlatma tasarımlarının örnek müze vitrinleri üzerinden araştırılarak incelenmesi ve değerlendirilmesi makalenin ana konusudur. Çalışmada, müzelerde hikâye anlatımının çekiciliğini ortaya çıkarabilecek vitrin tasarımının ve aydınlatma düzeninin tespit edilmesi, müze deneyimine katkısı ve tasarım bütünü içerisinde yerinin vurgulanması amaçlanmaktadır.

Çalışma kapsamında çağdaş müze sergi mekânlarında düzenlenen ve görsel konfor koşullarını sağlayacak vitrin aydınlatma tasarım ilkeleri, örnek vitrin aydınlatma tasarımları üzerinden incelenecektir. Araştırmanın, çağdaş müze sergileme mekânlarının kurgusunun yapılmasında önemli bir tasarım öğesi olan vitrin aydınlatma tasarımlarının planlama aşamalarında yapılacak çalışmalara katkı sağlayacağı düşünülmektedir. Bu amaç doğrultusunda hikâye anlatımının vitrin ve vitrin aydınlatma tasarımı ile birlikte görsel konfor ve müze deneyimine etkisi; sergi mekânları için örnek çalışma olması açısından irdelenerek değerlendirilecektir. Araştırma, nitel araştırma yöntemlerinden betimsel tarama modeli kullanılarak gerçekleştirilmiştir.

\section{Tanım ve Kavramlar}

\section{1. Çağdaş müzelerde sergi mekânı}

Çağdaş müzeler; geçmişten gelerek yerine getirmeye çalıştığı işlevlerinden öte bir anlayışla, koleksiyonlarını sadece göstermek, korumak, belgelemek dışında, mekânın varlığını öne çıkarma tarzını geliştirme çabasındadır. Yeni bir kavramın oluşmasına neden olan bu anlayış çerçevesinde sergileme için ana hedef, müzenin ziyaretçileri ile iletişim bağını kurarak, sadece objelere bakarak değil, dokunarak öğrenebilecekleri tasarım açısından güçlü mekânlar sunmaktır. Sergi mekânlarını ziyaretçisinin, gezintisini koleksiyonlarından kopmadan sürdürebilmesi için teknoloji tabanlı araçlar yardımıyla kurgusal olarak tasarlama çabası, mekân içindeki birçok unsurun dönüşüm geçirmesine ya da farklı bir bakışla ele alınmasına neden olmaktadır. 


\subsection{Müze sergi aydınlatması}

Işık; biçim ve dokuyu vurgulayan, sınırları belirgin kılan ya da bulanıklaştıran, bir özelliği gizlediği gibi diğer özelliği de açığa çıkaran ve mesafeleri küçülttüğü gibi aynı zamanda büyütebilen bir kaynaktır (Altan, 1993, s.80). Aydınlatma ise; ışığın işlevsellik veya estetik görünüm elde edilebilmesi için kullanılmasıdır (URL-1).

Yaşamın içinde vazgeçilmez bir yeri olan aydınlatma, müze sergileri için de hem iletişim ağını kuran hem de mekânın algılanmasına etki eden bir öneme sahiptir. Aydınlatma, müze sergi mekânlarının tasarımında önemli bir tasarım öğesi olduğu gibi aynı zamanda estetik görünüm kazandırdığı tasarımı müzenin ziyaretçisine gösteren bir tasarım bileşenidir. Bu doğrultudaki gereksinimle elde edilen aydınlatma sergi mekânını estetik gösterebileceği gibi hatalı uygulamalar nedeniyle diğer tasarım bileşenlerinin görsel olarak etkisini zayıflatabilmektedir. Çağdaş müzelerde uygulanan farklı aydınlatma teknikleri ve yeni çözümler ile sergilenen nesnelere farklı ölçülerde vurgu yapılabilmektedir. Çağdaş müzelerde etkileşimi artıran sergi aydınlatması çok öne çıkmadan mekânla bütünleşebilmelidir.

\subsection{Müzelerde hikâye anlatımı ve tema}

Müzelerin sergilerinin, ziyaretçisinin varlığının odak noktasına getirildiği deneyimlere açık mekânlarında, canlı, dinamik etkiler bırakmak amacıyla dönüşüm geçirdiği görülmektedir. Öğretici mekânların kurgulanmasının altındaki temel düşünce, müze deneyimini kişiselleştirme çabasıdır. Deneyimi kişiselleştiren ve ziyaretçinin bütün algılarını kullanması ile öğreticiliği kolaylaştıran anlayışın merkezinde, nesnelerin ya da koleksiyonun hikâyeleri ve sergi konusunun teması ile anlatılması fikri vardır. Bu düşünce, ziyaretçilerin hikâyesi ile anlatılan nesnenin üzerinde düşünce üretebilecekleri, yorum yapabilecekleri ve sadece görerek değil dokunarak algılayabilecekleri anlayışı içine almaktadır.

Hikâye, daha geniş bir anlatıda sergiyi yerleştiren yorumlayıcı bir araçtır (Hughes, 2010, s.26) ve anlatımın olması için bir hikâyenin olması gerekmektedir (Velarde, s.49). Hikâye anlatımında ziyaretçilerin beklentilerine verilebilecek en iyi yanıt insan faktörünün en doğru şekilde ele alınması ile gerçekleştirilebilir. Öncelikli olarak sergiyi gezecek ziyaretçilerin mekân ile olan psikolojik ve fizyolojik ilişkilerinin saptanması ziyareti kolaylaştıran ortamın sağlanmasına neden olacaktır (Aykut, 2017, s.241). Bu nedenle aydınlatma gibi nesne ile ziyaretçi arasında iletişimi sağlayan tasarım öğelerinin görsel konforu sağlayacak ve yorgunluk yaratmayacak biçimde ve nitelikte çözülmesi gerekmektedir.

\section{Müzelerde Aydınlatma Tasarım Kriterleri ve Görsel Konfor}

Müzelerin sergileme mekânlarının hikâye anlatımını destekleyen tasarım öğelerinin başında aydınlatma tasarımı gelir. Hikâye anlatımının ziyaretçiler tarafından çekiciliğinin artırılabilmesi ve algılanabilmesi için iyi görme koşullarının sağlanabildiği kaliteli bir aydınlatma tasarımına intiyaç vardır. Anlatının güçlü olması iyi bir aydınlatma tasarımını gerektirmektedir ve ziyaretçinin müze deneyimine konfor sağlamaktadır.

Çok çeşitli kriterleri karşılaması gereken müze aydınlatmalarının ana amacı koleksiyonlarını ya da nesneleri görünür kılmalarını sağlamaktır. Ziyaretçilerin müze deneyimine büyük ölçüde olumlu katkı sağlayabileceği gibi olumsuz etkileyebileceği de göze alınması gereken önemli bir konudur. Müze yönetiminin dikkate alması gereken bir tasarım öğesi olan aydınlatmanın, ışığın müze nesnelerine zarar vermeden düzenlenmesi gerekmektedir. Bu nedenle dikkate alınması gereken bir dizi faktör 
vardır. Bunlar; bakım, enerji verimliliği, estetik, renk sıcaklığı, titreme, uzun ömür gibi konulardır. Müze aydınlatması kararlarının alınmasında, bu kriterlerin özenle üzerinde durulması gerekmektedir (Garside, 2017, s.3). Bu bölümde müzelerde aydınlatma tekniği, aydınlatmanın renk niteliği, yansıma, parlama, kamaşma ve gölge etkisi incelenecektir.

\subsection{Müzelerde aydınlık düzeyi}

Mekânın anlamlandırılmasında önemli etkisi olan ışık, kişinin beğenme duygusunu artıracak algılamaya neden olur (Turgay, 2011, s.173). Bu nedenle aydınlatmanın gerçekleştirilmesinde hedeflenen konu; belli bir aydınlık düzeyinin elde edilmesi değil, iyi görme koşullarının sağlanması olmalıdır. Aydınlığın niceliğinden çok niteliğine ve aydınlık düzeninin özelliklerine bağlı olarak görsel konforun sağlanması gerekir. Bazı durumlarda nesnenin çevresi ve belli yüzeyleri aydınlatılarak özel görünümlerle nesne hiç aydınlatılmadan iyi görme koşulları sağlanabilmektedir. Müzelerde iyi görsel konforun sağlanabilmesi, öngörülen değerlerin üstüne çıkarılması anlamına gelmez. Bazı nesneler vardır ki 30 lüks, 50 lüks gibi düşük değerler verilerek aydınlık düzeylerinde iyi görme koşulları elde edilebilmektedir. Aydınlatılmak istenen nesnenin biçimsel, dokusal, renksel ve boyutsal gibi özellikleri aydınlığın niteliğini belirleyen unsurlardır. Bu nedenle aydınlık düzeyinin belirlenmesinde nesnenin bütün özelliklerinin dikkate alınması gerekmektedir (Sirel, 1997, s.6-7). Dikkate alınması gereken bir diğer konu da aydınlık düzeyi ile ilgili gereksinimin değişkenlik göstermesidir. Genç ve yaşııya göre aydınlık düzeyi büyük oranda değişebildiği gibi, kişiden kişiye, günün zaman aralığına ve yorgunluğa bağlı olarak da değişebilmektedir (Sirel, 1992, s.3). Sergileme hacimleri için aydınlık düzeyi 50 lüks ve 150 lüks ile sınırlandırılmaktadır (Kılıç Sirel, 1992, s.1).

\subsection{Aydınlatmanın renk niteliği}

Işık kaynağının tayfsal özelliklerine bağlı olarak nesnelerin renkleri algılanır. Nesnelerin görünen renginin değişmesini ve aydınlatılmasını sağlayan, ışığın tayfı ile ilgili bir durumdur. Renkleri istenildiği gibi görmenin yolu ise tercih edilen ışığın tayf yapısı ile ilgilidir (Sirel 1992, s.8). "Beyaz ışığın bileşenlerinden, rengi, renkli yüzeyin rengine yakın olanlar, yakınlıkları oranında, daha büyük yansır, daha uzak olanlar da, uzaklıkları oranında daha küçük yansır." (Sirel 2011, s.2). Renk açıklık koyuluk açısından değerlendirildiğinde, açık renkli yüzeylerin üzerine düşen ışık akısını büyük oranda yansıtan yüzey oldukları görülür. Açık renkli yüzeylerin koyu renkli yüzeylere göre ışıklılığı fazla olur. Tavanda ve duvar yüzeylerinde açık renkli yüzeyler arka planı koyu olan vitrinlerin camlarında görünürler (Kılıç,1985, s.99). Bu nedenle arka planı koyu olan vitrin camı üzerinde oluşabilecek bu tür görüntüleri önlemek için tavan ve duvarların koyu renk tonunda düşünülmesi gerekmektedir.

\subsection{Yansıma}

Bir nesneden göze gelen ışık miktarı, yüzeye çarpan ışığın miktarına ve yansıyan ışığın oranına bağlıdır (Adelson, 2000, s.339). "Yansıtıcı doğası nedeniyle, ışık görme ve görünürlüğü birleştirir, böylece ışık olmadan ne görme ne de görünür bir şey olamaz. Aslında, görünür şeyleri hem 'güzel' hem de 'iyi' olan şekillere dönüştüren ışıktır." (Gadamer, 2004, s.477). Ayrıca vitrinlerin ön camındaki parlak nesnelerin yansımasını önlemek için, parlak nesneler 'rahatsız edici bölge' dışında tutulmalıdır. Resim 1, üç farklı vitrin türü için rahatsız edici bölgeleri göstermektedir (Lighting Guide 8, s.58). 


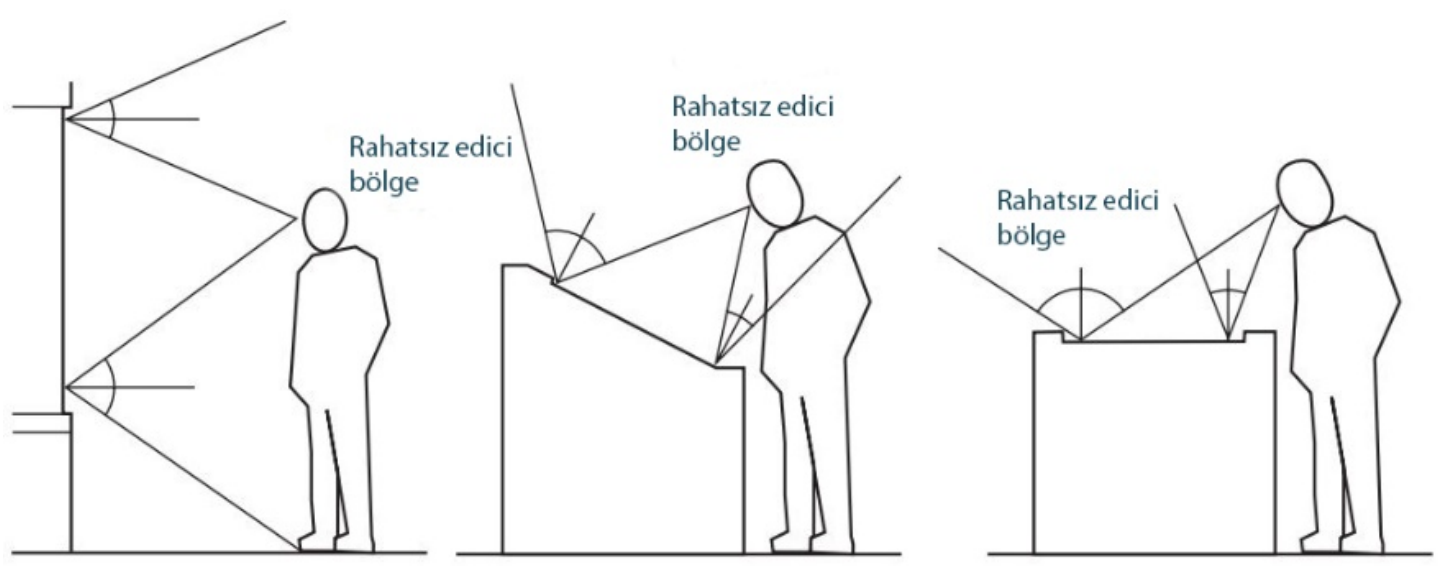

Resim 1. Vitrin Yüzeyinde Rahatsız Edici Bölgeler (Society of Light and Lighting , 2015, s58)

\subsection{Parlama ve kamaşma}

Aydınlatma, bir yüzeye düşen ışık miktarıdır. Parlaklık ise bir yüzeyden göze gelen görünür ışık miktarıdır (Adelson, 2000, s.341). Parlama, görüş alanının genel parlaklığına kıyasla doğrudan veya yansıyan armatürlerin, pencereler ve diğer ışık kaynaklarının çok parlak olduğu durumlarda ortaya çıkar. Görünürlük üzerinde zararlı etkiler yaratacağı için ışık kaynaklarından gelen parlamayı ve yansımayı ortadan kaldırmak önemlidir (Lighting Guide 8, s.6).

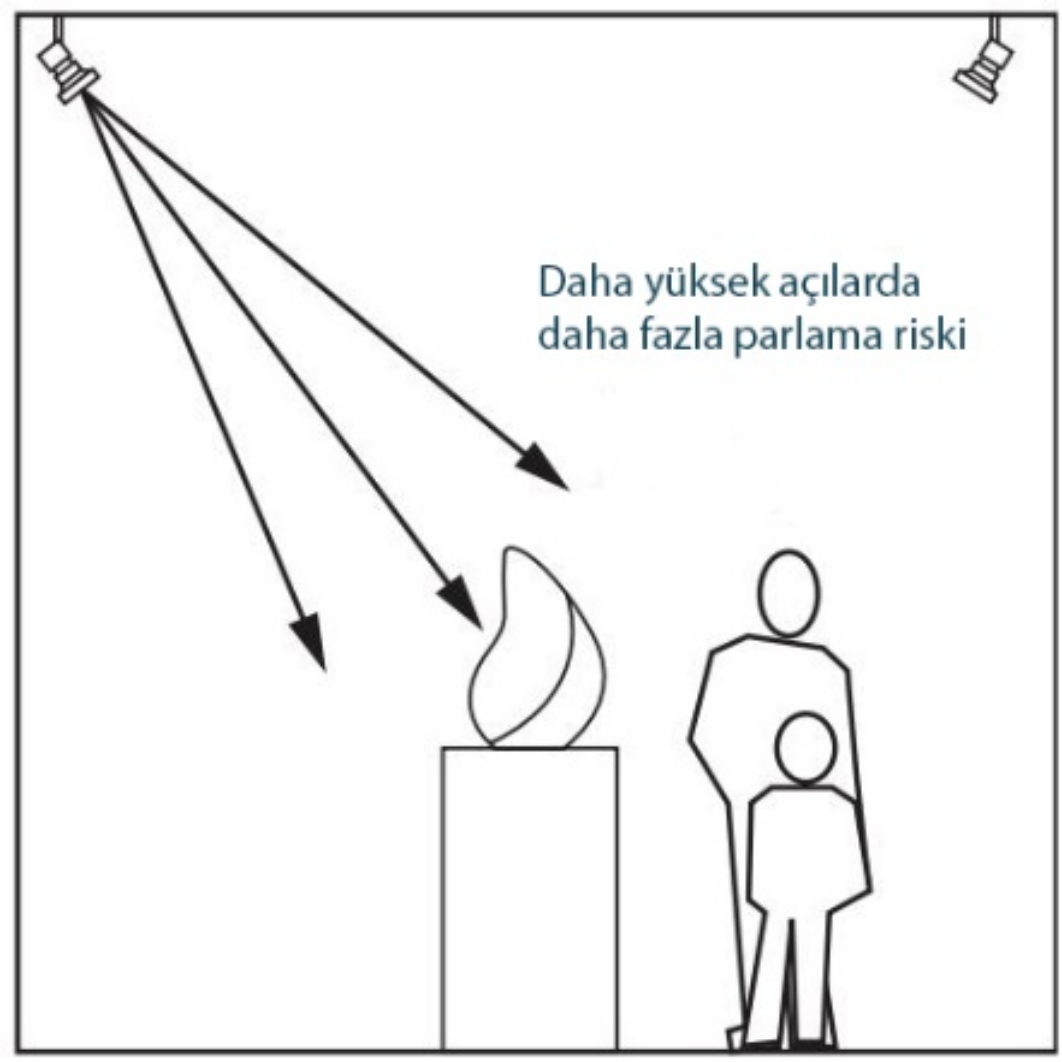

Resim 2. Daha yüksek açılarda daha fazla parlama riski (Society of Light and Lighting, 2015, s.6.)

Kamaşma da, ışıklılıkların uygun olmayan dağılımları ya da aşırı bir karşıtlık sonucunda, nesnelerin niteliklerinin ya da detaylarının fark edilmesinde güçlük oluşturan görme koşullarıdır (Sirel, 2012, s.90). Ortam ışığı ise bir mekândaki genel 
ışıktır. Ortam ışığının yanı sıra belirli nesneleri ve etkinlikleri vurgulamak amacıyla, doğrudan verilen ışık ile farklı teknikler bir araya getirilerek odaklanma sağlanabilmektedir. Gözü kamaştırıcı ışık, parlama ve görüntüyü engelleyici gölgeler ziyaretçiler için rahatsız edici olacağı gibi görme bozukluğu olan ziyaretçi için de sergiyi erişilemez duruma getirebilmektedir. Aynı zamanda çoğu insanın gözlerinin farklı ışı seviyelerine uyum sağlaması zaman alan bir durumdur. Sergi tasarımcıları bu durumda bir mekândan diğer mekâna geçişteki sorunu önleyebilmek için geçiş bölgeleri tasarlamalıdır (McLean, 1993, s.142). Diğer taraftan gün ışığından karanlık bir alana geçişte olduğu gibi kontrast seviyeler arasında çok yüksek fark olmaması gerekir. İnsan gözünün uyum sağlaması için zamana intiyacı olacaktır. Bu nedenle dramatik değişimlerden kaçınılmalıdır. Aksi takdirde ziyaretçiler için rahatsız edici olabileceği gibi deneyimi de olumsuz yönde etkileyebilecektir (Kennedy, 1994, s.57). Aydınlatma, sergi mekânının konfor hissini veren önemli bir bileşen olması nedeniyle, ortaya çıkabilecek olası tüm olumsuzlukların planlama aşamasında dikkate alınması gerekmektedir.

\subsection{Gölge etkisi}

Nesnelerde, dokularda, farklı yüzeylerde ve mekânlarda ışığın doğrultusal yapısına göre birbirinden farklı gölgeler oluşur. Estetik değerlerin vurgulanmasında, ortaya çıkarılmasında, güçlendirilmesi ya da gizlenmesinde etkili olan gölgeler görsel algıyı olumlu ya da olumsuz yönde etkileyebilmektedir (Sirel 1992, s.4). Işığın doğrultusal yapısına göre sert-yumuşak gölgeler, saydam ve kara gölgeler oluşmaktadır. Çok özel doku ve gölgelerin seçilmesini kolaylaştıran sert gölgelerin sınırları kesindir. Estetik açıdan nesnelerin üç boyutsal özelliklerini yok edebilir. Örneğin; koninin piramit gibi algılanmasına neden olabileceği gibi yumuşak görüntülerin keskin görünmesine neden olabilmektedir. Yumuşak gölge ise gölgenin giderek saydamlaşması ile oluşan ve sınırları kesin olmayan bir gölgedir. Nesneye olan uzaklığına göre ışık kaynağının boyutu ne kadar büyürse gölge de aynı oranda yumuşak görünmeye başlayacaktır. Bunların yanı sıra ışık kaynağı dışındaki bir ışık kaynağından ya da çevredeki yüzeylerden yansıyarak gelen ışıkla aydınlanan gölgeler de oluşur. Aydınlandıkça saydamlaşan bu gölgeler dışında, hiçbir biçimde aydınlanmayan gölgeler de vardır. Bu tip gölgeler ise kara gölge olarak adlandırılırlar. Kısa süreli olarak etkili ve çekici özelliği olmasına rağmen görsel algılamada eksikliklere neden olabilmektedir. Uzun süreli olduğunda yorucu bir etkisi olabilen kara gölgeli aydınlıklar, vitrin aydınlatması için tercih edildiklerinde başarılı sonuçlar elde edilebilmektedir (Sirel 1992, s.6-7). Işık ve gölge belirliliği ilgi çekici, ilginin sürekliliğini sağlayıcı ve canlılık verici bir etki yaratmaktadır (Güngör, 2005, s.96). Bu durumda gölge desenleri ve ışık ile objelerin üç boyutlu şeklini ve dokusunu oluşturarak görsel ilgiyi çekmek mümkün olabilmektedir (Ching, 2012, s.261).

\section{Müze Sergileme Vitrinleri ve Aydınlatma Tasarımının Hikâye Anlatımına Etkisi}

Vitrinler, müzeler için sergileme mekânının oluşmasını sağlayan önemli bir bileşendir. Müzelerde nesneleri korumak dışında ziyaretçilerin nesneleri ya da koleksiyonları en uygun şekilde görmelerini, bilgilenmelerini sağlamak amacıyla tasarlanırlar (Aykut, 2017, s.230). Vitrinin büyüklüğünü ve boyutlarını, içinde sergilenecek olan nesnelerin; biçim, renk, doku ve ölçüleri belirler. Vitrinin biçimini ortaya koyan, nesnenin genel özellikleridir. Aydınlatma tasarımı da nesne ve vitrin arasındaki ilişkiye bağlı olarak gerçekleştirilir ve iki veriye göre yapılan aydınlatma biçimi ve aydınlatma düzeni arasında değişmez bir ilişki oluşur. Sergileme nesnesindeki bir değişiklik; vitrininin biçimini, vitrinin biçiminde meydana gelen değişiklik ise aydınlatma düzenini etkileyecektir (Kılıç Sirel, 1992, s.2). Nesnenin özelliklerine göre biçimlenen vitrinlerin 
tasarımını etkileyen bir diğer önemli faktör ise serginin hikâyesine uygun özellikte ve ziyaretçiyi mekân tasarımı ile etkileşime geçirecek biçimde tasarlanması gerektiğidir (Aykut, 2017, s.226). Her vitrini minyatür tiyatro sahnesi olarak düşünmek ve her uygulama için küçültülmüş bir tiyatro aydınlatma tekniklerine bakmak iyi bir yöntem olabilir. Bir tiyatro sahnesinde olduğu gibi vitrin aydınlatma tasarımında nesneler bir aktörler ya da karakterler gibi görülerek sahnede ortaya çıkarılabilir. Ziyaretçinin sergilenen nesneden en iyi odaklanabilmesini sağlamak için aydınlatmanın en yüksek kalitede düzenlenmesi gerekmektedir (Shaw (a), s.1). Tiyatro aydınlatma teknikleri kullanılarak dinamik hareketli efektler ile dramatik bir sunum gerçekleştirilebilir. Bu tekniklerle aydınlatma, vitrinlerde yorumlayıcı ve bağlamsal bir rol oynayabilir. Örneğin, UK Jersey Müzesi denize odaklanan bir sergi alanına sahiptir. Sergi alanında denizin sürekli değişen sergi görünümü ve gökyüzündeki hava koşulları gibi efektler aydınlatma ile yaratılmıştır. İskoçya Ulusal Müzesi'nde benzer bir örnekten bahsedilebilir. Sergi konusu olarak balık türleri, yaşadıkları yerler, besin zincirleri anlatımaktadır. Vitrinlerinde ise su yüzeyini tasvir etmek için vitray kullanılmıştır. Tasvir edilen habitata uygun farklı sualtı hisleri yaratmak için aydınlatma tekniği kullanılmıştır. Ziyaretçileri vitrine çekmek ya da dâhil etmek için vitrin boyunca devam eden dalgalanma desenleri ile camın dokusu oluşturulmuştur (Shaw (b), s.3). Hikâyesi ile anlatılan serginin temasını destekleyici form, renk ve nitelikte tasarlanması yanı sıra içinde yer alan nesnelerin vurgulanarak ya da tiyatro aydınlatma teknikleri kullanılarak öne çıkarılması ziyaretçileri vitrine teşvik edecektir.

Vitrin tasarımının çekiciliğini etkileyen bir diğer önemli etken ise kompozisyonun içeriği ve içeriğin vitrin içindeki yerleşimidir (Belcher, 1991, s.125). Vitrin içindeki objeler çekiciliği artıran bir kompozisyon oluşturacak biçimde düzenlenmezse sergi amacına ulaşamayabilir. Ziyaretçinin ilgisini çekebilmek için farklı boyut, doku, renk ve tonlara sahip objelerin ortak ve farklı özelliklerini ortaya çıkaracak şekilde düzenlenmesi gerekir. Bunu başarabilmek ve odaklanmayı sağlayabilmek için objelerin görünürlüklerinin kompozisyon içinde kaybolmadan yerleştirilmesi önem kazanmaktadır (Mohanty, 2014, s.50). Danimarka'nın denizcilik tarihini anlatan sergide de ziyaretçilerin ilgisini çekecek nitelikte objelerin vitrin içinde yerleştirildiği ve sergi konusunun temasına uygun olarak vitrinlerin tasarımının gerçekleştirildiği görülmektedir.

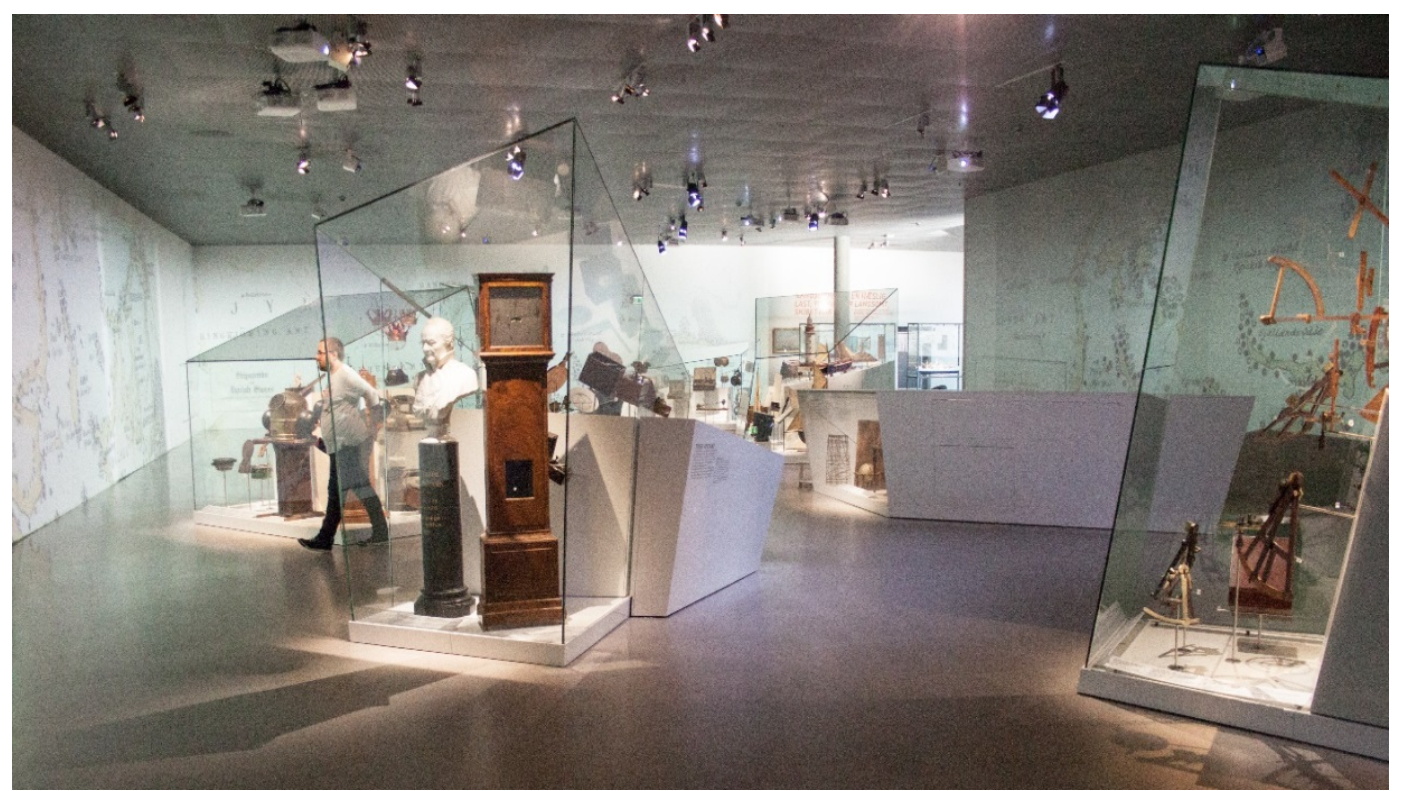

Resim 3. Denizcilik Temasında Buzdağı Formunda Tasarımları Gerçekleştirilen Vitrin Örneği (URL-2) 


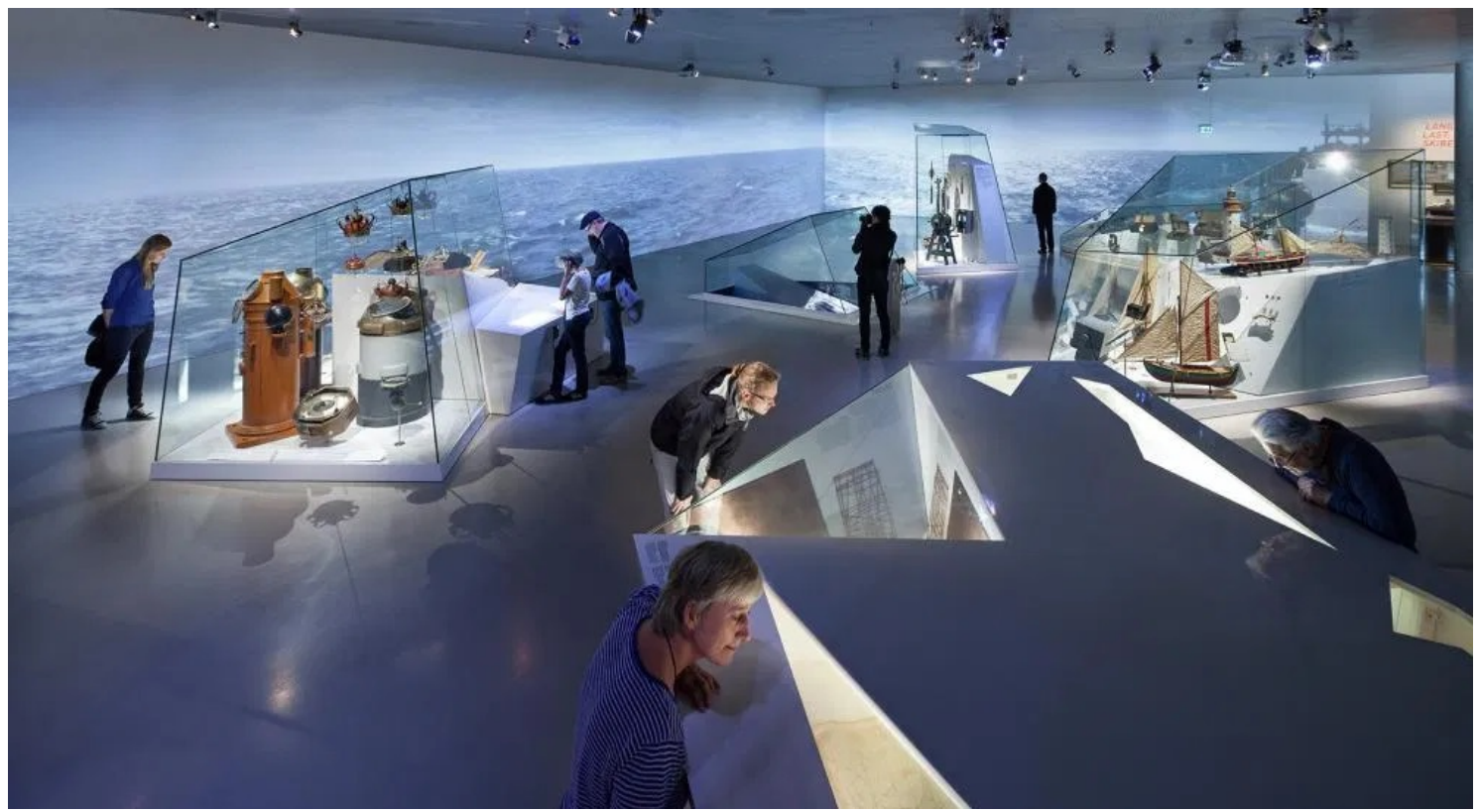

Resim 4. Danimarka Denizcilik Müzesi (URL-3)

Danimarka Denizcilik Müzesi'nde düzenlenen serginin temelini oluşturan metafor; denizde maceraları deneyimlemek, uzak kıyıları keşfetmek için özlemin hayal edilmesiyle başlayan bir yolculuktur. Sergi kapsamında Danimarka'nın denizcilik tarihi, denizcilik, liman, savaş ve ticaret gibi temaların güncel bir yaklaşımla anlatıldığı görülmektedir. Müze binasının kendine özgü heykel nitelikleri serginin hikâyesine dâhil edilmiştir. Mimari ve iç mekânların birbirini tamamladığı sergi alanında çok dar alanlar, savaşın baskıcı atmosferini uyandırmak için kullanılırken, daha geniş alanlar ise denizin açıklığını ve tema olarak işlenen çağdaş küreselleşmenin büyük ölçeğini vurgulamak için düzenlenmiştir. Tümü yeraltında olan sergi alanlarında, gemideki lumbuzların, denizcilere ait objelerin sergilendiği vitrinlere dönüştürüldüğü görülmektedir (URL-4). Bu yaklaşımla, vitrinlerin ziyaretçinin müze deneyimini etkileyen bir faktör olarak ele alınması ya da yorumlanması bağlayıcı bir unsur olarak öne çıkmaktadır. Temaların betimlendiği sergi tasarımında, ziyaretçilerin hikâyeye dâhil olmalarını sağlamak için etkileyici bir anlatımla vitrin tasarımlarının bir araç olarak kullanılması dikkat çekicidir. Gemilerin gövde kısımlarında ışık ve havayı içeriye almak için kullanılan dairesel pencerelerin (URL-5) sergi mekânında tasvir edilen hikâyeyi destekleyici nitelikte vitrin olarak kullanılması, sergileri unutulmaz kılan ve dramatize eden bir unsur olarak değerlendirilebilir. 


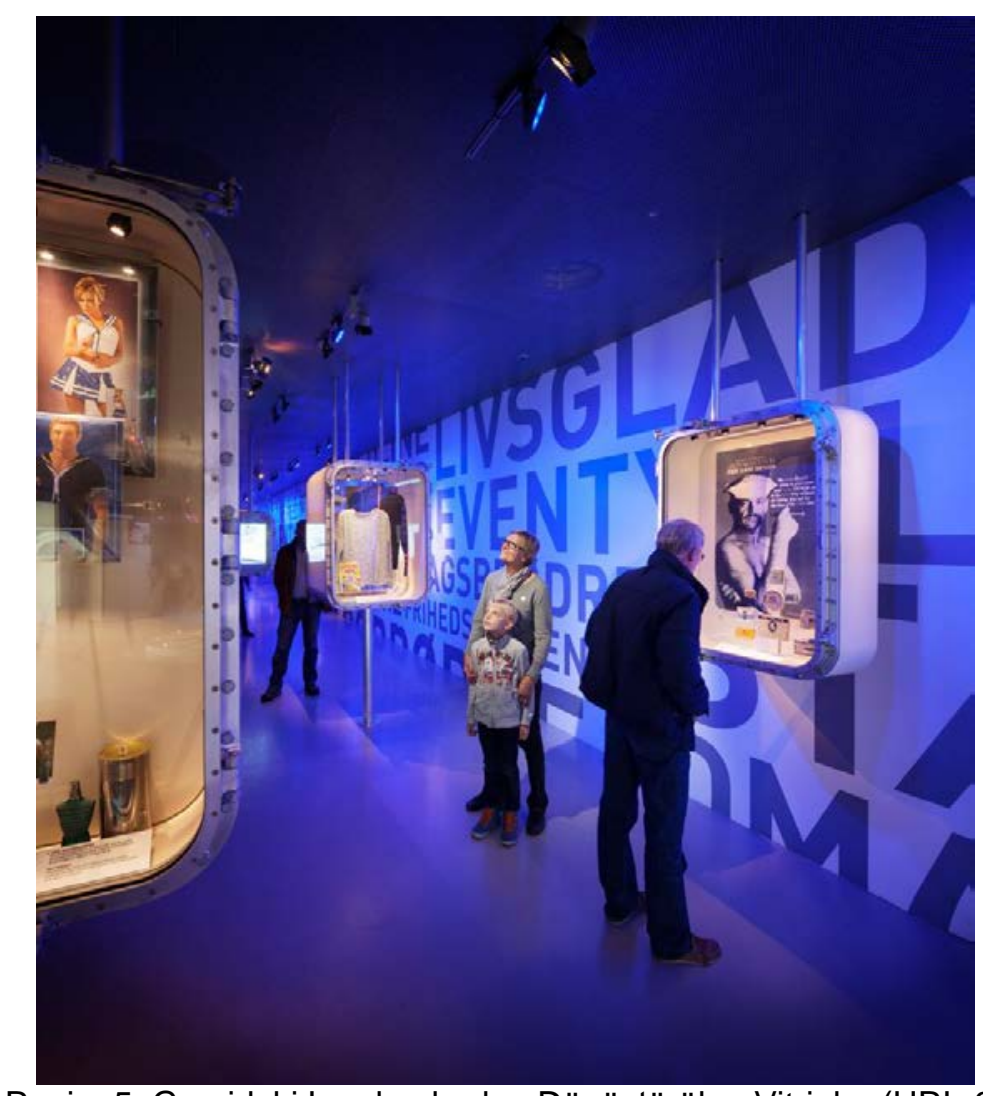

Resim 5. Gemideki Lumbuzlardan Dönüştürülen Vitrinler (URL-6)

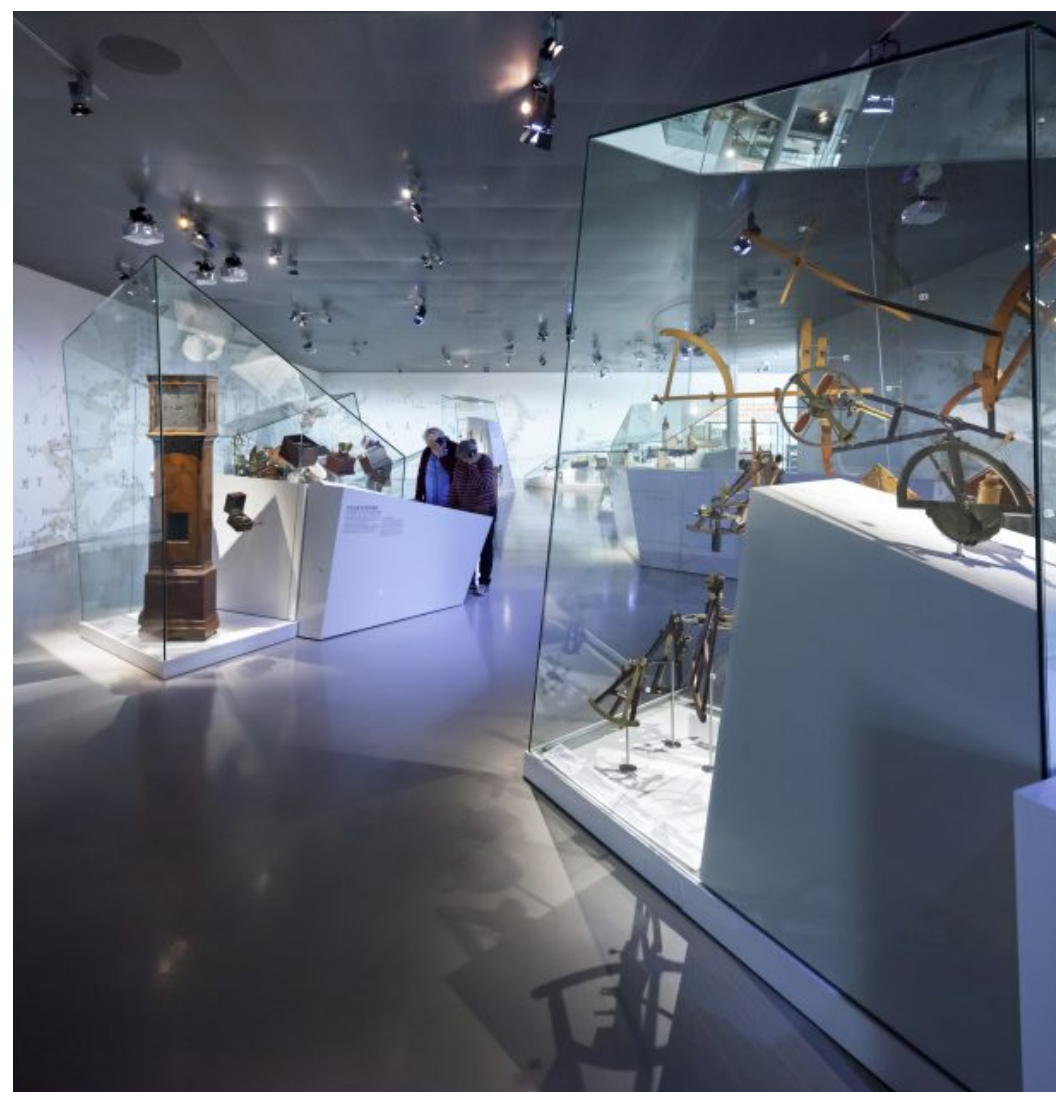

Resim 3. Denizcilik Temasında Buzdağı Formunda Vitrin Tasarımlarının Gerçekleştirildiği Vitrin Örneği (URL-7) 


\section{Müze Sergileme Vitrinlerinin Mekân ile İlişkisi}

Sergileme vitrinlerinin aydınlatılmasında ve koşulların sağlanmasında bir takım zorluklar yaşanabilmektedir. Vitrinlerin büyüklüklerine, tiplerine, içinde sergilenen nesnelerin özelliklerine, ışık kaynağının içinde ya da dışında yer almasına bağlı olarak sorunlar yaşanabilir. Bu sorunlar arasında en zor olanı, ışık kaynaklarından gelen ışığın vitrinin cam yüzeylerinde yansıması ile ortaya çıkmaktadır. Bu durumda ziyaretçiler sergilenen nesneler yerine cam yüzeyi üzerinde ışık kaynaklarını, diğer vitrinleri, pencereleri ve kendini görebilmektedir (Kılıç Sirel, 1992, s.1). Kılıç Sirel, vitrin tasarımlarını ve mekânı biçimlendiren faktörleri şöyle sıralamaktadır. İçinde vitrin yer alan tüm mekânların duvar, tavan ve döşeme yüzeylerinin ışıklıığı düşük, doygunluğu az olmalıdır. Vitrinler, cam yüzeylerinin yansıma bölgeleri içine diğer vitrinler (duvar vitrini, masa, sıra tipi ya da büyük sergileme vitrini) girmeyecek şekilde konumlandırılmalıdır. Vitrin içindeki ışıkııı̆ın düzgün dağıımına dikkat edilmelidir. Nesnelerin tümü niteliklerine uygun ölçüde aydınlatılmalıdır. Vitrin içinde yer alan nesneler ışıklılığın düzgün dağılımı gerçekleştirilmediğinde fazla aydınlıkta kalan benzer nesneler diğerlerine oranla ilgi odağı haline dönüşebilirler. Diğer taraftan yatay camları olan masa ve sıra tipi vitrinlerin yüzeylerinde tavandaki ışık kaynaklarının görüntüsünün oluşmasını engellemek için mekânın tavanlarının koyu renkli olması ya da ışık kaynaklarının göze gelmesini engelleyen bir sistem geliştirilebilir (Kılıç, 1985, s.116-118). Gün ışığının cam yüzeylerine çarparak oluşturduğu parıltıyı önlemek için pencerelerden uzak noktalara yerleştirilmesi uygun olur (Peters, 1995, s.75). Bir diğer önemli konu da vitrin tasarımlarının birbirini engellemeyecek ve bir diğerinin üzerinde gölge oluşturmayacak şekilde yerleştirilmesidir. Ziyaretçilerin dolaşım alanları üzerinde doğru yerde konumlandırılması ve yönlerinin de dolaşımla ilişkilendirilerek tasarlanması ziyaretçilerin daha çok verim almasını sağlayacaktır.

\section{Sonuç}

Müze sergi vitrinleri, mekân içinde sundukları nesneler ya da koleksiyonları ziyaretçiler ile buluşturan önemli tasarım öğeleridir. İçinde barındırdıkları nesneleri ziyaretçiler ile tanıştıran vitrinler yüzyıllardır bir kasa, kutu ya da bir dolap formunda tasarlanmışlardır. Bu çalışmada, çağdaş müze sergileme mekânlarında vitrin tasarımı ve vitrin aydınlatma tasarımlarının ziyaretçiyi teşvik edici nitelikleri ve aydınlatma tasarımı ile ilgili hususlar incelenmiştir. Aydınlatma tasarımı müze sergileme mekânlarına çekicilik kazandıran, biçimlendiren, etkileşimi artıran ve mekânı canlı kılan önemli bir tasarım bileşenidir. Aydınlatma tasarımı, mekânın diğer tasarım öğelerini birleştirici özelliğe sahiptir. Sergileme mekânı içinde yer alan bölümler arasındaki geçişi sağladığı gibi vurgulanmak istenen nesne ya da mekânın herhangi parçasına ilişkin ayrıntıları da öne çıkarmak için ideal bir çözümdür. Ziyaretçilerin mekâna çekiciliğinin artırılmasında etkisi yüksek olabildiği gibi hatalı uygulamalarla dikkat dağıtıcı, rahatsız edici boyutta tasarlandığında, odaklanmayı olumsuz yönde etkileyebilme özelliğine de sahiptir. Bu durum genel aydınlatma uygulamaları için geçerli olmakla birlikte vitrin aydınlatmaları için de geçerlidir. Kamaşma, yansıma gibi olumsuz etkilerin yaşanmaması için belli kurallar çerçevesinde uygulamaların gerçekleştirilmesi gerekir. Işık kaynaklarının hem içeriden hem dışarıdan hatalı yerleştirilmesi istenmeyen bir takım sonuçlar doğurabilir. Bunların engellenmesi için uygulamadaki adımlar ve hususlar özenle yerine getirilmelidir. Çalışma kapsamında, vitrin aydınlatma tasarımlarının bu hususlar dışında ziyaretçiyi kendine çekebilmesi ve teşvik edebilmesi için hikâyenin temasını anlatan ve mesajı iletecek form ve işlevsellikte tasarlanması gerektiği vurgulanmıştır. Hikâye anlatımının vitrin tasarımı ve aydınlatmasına etkileyecek şekilde tasarlandığında etkileşimli müze deneyimi gerçekleştirilmiş olacaktır. Bu da ziyaretçilerin müzede 
geçirdikleri zaman dilimi içerisinde sergiden kalıcı bilgi, birikim ve güzel hislerle yararlanmalarına etki edecektir•

\section{Kaynaklar}

Altan, İlhan. "Mimarlıkta Mekân Kavramı". İstanbul Üniversitesi Psikoloji Çalışmaları Dergisi, 19(1), İstanbul 1993, s. 78-88.

Adelson, Edward. H. "Lightness Perception and Lightness Illusions", in The Cognitive Neurosciences, (Ed: M. Gazzaniga), MIT Press,Cambridge, MA, 1999, s.339-351.

Aykut, Züleyha. "Müze Sergilemelerinde İzleyici-Sergi Etkileşimi Bağlamında Mekân Tasarımı", International Journal of İnterdiciplinary and İntercultural Art, 2, 2017, 219242.

Belcher, Michael, Exhibitions in Museums, 1.Baskı, Smithsonian Institution Press., Leicester 1991.

Ching, Francis, D. K. ve Binggeli, Corky, Interior Design Illustrated, John Wiley \&son., United States of America, 2012.

Gadamer, Hans-Georg, Truth and Method, 2. Baskı, Continuum, New York 2004.

Garside Daniel, Curran Katherine, Korenberg Capucine, MacDonald Lindsay, Teunissen Kees, Robson Stuart, "How is Museum Lighting Selected? An Insight into Current Practice in UK Museums", Journal of the Institute of Conservation., 40(1), 2017, s. 3-14.

Güngör, Hulusi, Temel Tasar, 3.Baskı, Bilgisayar Destekli Baskı ve Reklam Hizmetleri Sanayi ve Ticaret Ltd. Şti., İstanbul 2005.

Hughes, Philip, Exhibition Design. 1.Baskı, Laurence King Publishing, London 2010.

McLean, Kathleen, Planning for People in Museum Exhibitions, 1.Basım, Associaion of Science-Technology, Washington 1993.

Kevan Shaw (a), Case Light Solutions.

(https://hosting.iar.unicamp.br/lab/luz/ld/Arquitetural/Museus/manuais/Display\%20Case \%20Lighting.pdf)

Shaw, Kevan ve Innes, Malcolm (b), "Museum and Gallery Lighting", October 27, 1993, revised June 1995.

Sirel, Şazi, Müzelerde ve Bürolarda Aydınlatma, YFU Yayın No:8, Yapı Fiziği Uzmanlık Uygulamaları Sanayi ve Ticaret A.Ş., İstanbul 1997.

Sirel Şazi, “Aydınlığın Niteliği”, Yapı Fiziği Uzmanlık Enstitüsü, İstanbul 1992.

Kennedy, Jeff, User Friendly: Hands-on Exhibits That Work, DC: Association of Science Technology Centers, Washington 1994.

Kılıç Sirel, Hülya, Müze Sergileme Vitrinleri ve Aydınlatılması, 1.Baskı, Yıldız Teknik Üniversitesi Mimarlık Fakültesi, İstanbul 1992. 
Kılıç, Hülya., Çağdaş Aydınlatma Tekniği Ve Günümüz Müzeciliği Verilerine Göre Müze Yapıları İçin Yeni Bir Mimari Yaklaşım, Fen Bilimleri Enstitüsü, YTÜ Basımevi, İstanbul 1985.

Mohanty, Subodha Kumar, "Technique of Display in Museums", Man in Society The Journal of Anthropology Department, Ed: Sabita Acharya, Post-Graduate Department of Anthropology, India 2014, s. 49-52.

Peters, Heather, Training Manual for Museum Development at Hue, Viet Nam Unesco, 1995.

Sirel, Şazi, Aydınlatma Sözlüğü, Yapı Fiziği Uzmanlık Enstitüsü, İstanbul 2012.

Sirel, Şazi, Öz Renk- Görünen Renk ve Aydınlatma, YFU, 2011.

Society of Light and Lighting. SLL Lighting Guide 8: Lighting for Museums and ArtGalleries, SLL, London 2015.

Turgay, Orkunt ve Altuncu, Damla, İç mekânda kullanılan yapay aydınlatmanın kullanıcı açısından etkileri, Cankaya University Journal of Science and Engineering 8(1), İstanbul 2011, s. 167-181.

Velarde, Giles, Designing Exhibitions, 1.Baskı, The Design Council, London 1988.

URL-1: https://www.aydinlatma.org/aydinlatma-nedir.html

URL-2:

https://upload.wikimedia.org/wikipedia/commons/2/2f/Danish_Maritime_Museum\%2C_i nterior\%2C_2017-08-02.jpg

URL-3: https://www10.aeccafe.com/blogs/arch-showcase/2013/12/08/danish-nationalmaritime-museum-in-helsingor-denmark-by-kossmann-dejong/ (11.12.2020)

URL-4:https://www10.aeccafe.com/blogs/arch-showcase/2013/12/08/danish-nationalmaritime-museum-in-helsingor-denmark-by-kossmann-dejong/

URL-5: https://en.wikipedia.org/wiki/Porthole

URL-6: https://www10.aeccafe.com/blogs/arch-showcase/2013/12/08/danish-nationalmaritime-museum-in-helsingor-denmark-by-kossmann-dejong/\#jp-carousel-190756

(11.12.2020)

URL-7: https://www.kossmanndejong.nl/project/maritime-museum-of-denmark/ (11.12.2020) 